\title{
Isolation and characterization of a conjugative plasmid from Legionella pneumophila
}

\author{
Clifford S. Mintz, ${ }^{1 *}$ Barry S. Fields ${ }^{2}$ and Chang-Hua Zou ${ }^{1}$ \\ ${ }^{1}$ Department of Microbiology and Immunology, University of Miami School of Medicine, Miami, Florida 33101, USA \\ ${ }^{2}$ Respiratory Diseases Branch, Division of Bacterial and Mycotic Diseases, National Center for Infectious Diseases, \\ Centers for Disease Control, Atlanta, Georgia 30333, USA
}

(Received 2 January 1992; revised 2 March 1992; accepted 11 March 1992)

\begin{abstract}
The conjugative properties of an indigenous $85 \mathrm{MDa}$ plasmid (designated pCH1) from Legionella pneumophila were studied. To determine if $\mathrm{pCH1}$ was transmissible by conjugation, mating experiments were performed between legionellae that harboured pCH1 and several plasmid-less recipients. Plasmid transfer was monitored by colony hybridization, using a cloned $21.0 \mathrm{~kb} \mathrm{Sal}$ restriction fragment from pCH1 as a probe. The results from these experiments showed that pCH1 could be conjugatively transferred into several strains of $L$. pneumophila serogroup 1 but not into strain Bloomington-2 (serogroup 3) or Escherichia coli. Southern hybridization experiments in which pCH1 DNA was used as a probe showed that pCH1 does not share homology with other indigenous $L$. pneumophila plasmids. There was no detectable DNA homology between pCH1 and $L$. pneumophila chromosomal DNA. Additional mating experiments revealed that pCH1 was unable to mobilize the L. pneumophila chromosome. The conjugative transfer of pCH1 into plasmid-less avirulent or virulent serogroup 1 strains did not alter the intracellular growth characteristics of these strains in U937 cells, a human-monocytelike cell line, or in the amoeba Hartmannella vermiformis. These results suggest that pCH1 does not contribute to the ability of $L$. pneumophila to enter or grow within eukaryotic cells.
\end{abstract}

\section{Introduction}

Legionella pneumophila, the causative agent of Legionnaires' disease, is a facultative intracellular pathogen capable of entering and multiplying in cultured animal cells (Dreyfus, 1987; Pearlman et al., 1988), free-living amoebae (Fields et al., 1986; Holden et al., 1984; Rowbotham, 1986; Newsome et al., 1985) and human mononuclear phagocytes (Horwitz \& Silverstein, 1980). At the present time, little is known about the bacterial factors that promote the intracellular lifestyle of this organism.

Plasmids have been reported to carry genes that contribute to the virulence of a variety of Gram-negative intracellular pathogens including Yersinia spp. (BenGurion \& Shafferman, 1981; Portnoy et al., 1981, 1984), Shigella spp. (Maurelli \& Sansonetti, 1988) and Salmonella spp. (Gulig, 1990). Several groups have identified plasmids in both clinical and environmental isolates of

\footnotetext{
* Author for correspondence. Tel. (305) 547 6310; fax (305) 5484623.
}

Abbreviation: mAb, monoclonal antibody.
L. pneumophila (Johnson \& Schalla, 1982; Knudson \& Mikesell, 1980; Maher et al., 1983; Mikesell et al., 1981). Early work indicated that the plasmids ranged in size from 23-85 $\mathrm{MDa}$ and did not confer an identifiable phenotype on strains that harboured them (Johnson \& Schalla, 1982; Maher et al., 1983). Despite the presence of these plasmids in L. pneumophila, their contribution to the ability of $L$. pneumophila to enter and grow within eukaroytic cells has never been evaluated.

Previous work from this laboratory (Mintz \& Shuman, 1988) using broad host range IncP and IncQ plasmids showed that conjugation is possible in L. pneumophila. This finding, along with the identification of an $85 \mathrm{MDa}$ plasmid in numerous L. pneumophila serogroup 1 clinical and environmental isolates (Schalla \& Johnson, 1982; Maher et al., 1983) suggested that certain indigenous $L$. pneumophila plasmids may be transmissible by conjugation.

In the present study, we evaluated the conjugative and virulence properties of an $85 \mathrm{MDa}$ plasmid (designated pCH1) from $L$. pneumophila. Our results demonstrate that $\mathrm{pCH} 1$ is self-transmissible by conjugation among serogroup 1 isolates of L. pneumophila. Also, $\mathrm{pCH} 1$ does 
Table 1. Bacterial strains

Abbreviations: $\mathrm{Km}^{\mathrm{r}}$, kanamycin resistant; $\mathrm{Nal}^{\mathrm{r}}$, naladixic acid resistant; $\mathrm{Rif}^{\mathrm{r}}$, rifampicin resistant; Sm${ }^{\mathrm{r}}$, streptomycin resistant; Trptryptophan auxotroph; $r^{-} m^{+}$, restriction minus modification plus; $r^{-} m^{-}$, restriction minus modification minus.

\begin{tabular}{|c|c|c|c|}
\hline Designation & Relevant characteristics & Comments & Source* \\
\hline $\begin{array}{l}\text { L. pneumophila } \\
\text { Philadelphia-1 } \\
\text { Pontiac-1 } \\
\text { NY26 } \\
\text { Ver 5 } \\
\text { Rockport } \\
\text { CH-1 } \\
\text { RH-1 } \\
\text { UH-2 } \\
\text { UPH-1 } \\
\text { OLDA } \\
\text { LpP } 2 \\
\text { LpP } \\
\text { SF3256 } \\
\text { SF3257 } \\
\text { Albuquerque-1 } \\
\text { Atlanta-1 } \\
\text { Atlanta-4 } \\
\text { AM511 } \\
\text { CS267 } \\
\text { CZ3001 } \\
\text { Bloomington-2 } \\
\text { CS2 } \\
\text { CS302 } \\
\text { Knoxville-1 } \\
\text { CS323 }\end{array}$ & 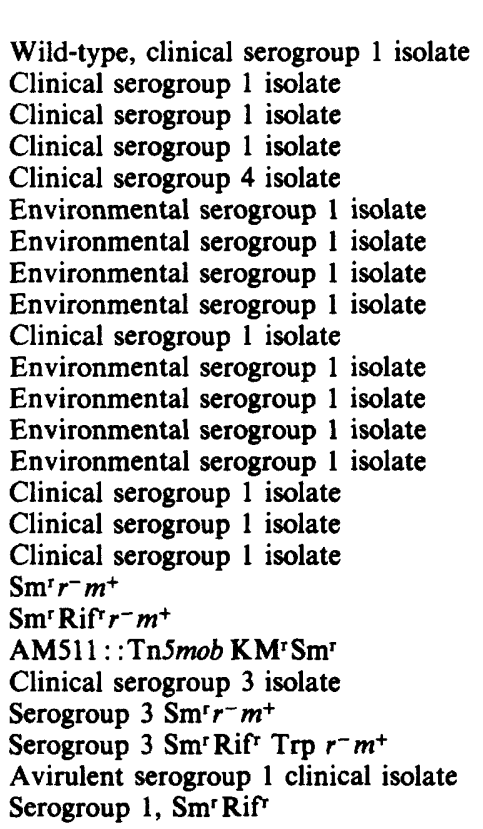 & $\begin{array}{l}\text { Plasmid-less } \\
\text { Plasmid-less } \\
\text { Plasmid-less } \\
\text { Plasmid-less } \\
\text { Plasmid-less } \\
\text { Contains an } 85 \mathrm{MDa} \text { plasmid } \\
\text { Contains } 45 \text { and } 85 \mathrm{MDa} \text { plasmids } \\
\text { Contains a } 45 \mathrm{MDa} \text { plasmid } \\
\text { Contains a } 33 \mathrm{MDa} \text { plasmid } \\
\text { Contains an } 85 \mathrm{MDa} \text { plasmid } \\
\text { Contains an } 85 \mathrm{MDa} \text { plasmid } \\
\text { Contains } 45 \text { and } 85 \mathrm{MDa} \text { plasmids } \\
\text { Contains an } 85 \mathrm{MDa} \text { plasmid } \\
\text { Contains an } 85 \mathrm{MDa} \text { plasmid } \\
\text { Contains an } 85 \mathrm{MDa} \text { plasmid } \\
\text { Contains a } 62 \mathrm{MDa} \text { plasmid } \\
\text { Contains a } 24 \mathrm{MDa} \text { plasmid } \\
\text { Derived from Philadelphia-1 } \\
\text { Spontaneous Rif mutant of AMSII } \\
\text { Plasmid-less } \\
\text { Plasmid-less, spontaneous Sm }{ }^{\mathrm{r}} \text { mutant of Bloomington-2 } \\
\text { Derived from CS2 } \\
\text { Plasmid-less } \\
\text { Derived from Knoxville-1 }\end{array}$ & $\begin{array}{l}- \\
- \\
\text { A. Marra } \\
\text { This study } \\
\text { This study } \\
\text { M. Horowitz } \\
\text { This study } \\
\text { This study } \\
\text { R. Miller } \\
\text { This study }\end{array}$ \\
\hline $\begin{array}{l}\text { E. coli } \\
\text { DH } 5 \alpha\end{array}$ & $\mathrm{Nal}^{\mathrm{r}} \boldsymbol{r}^{-} \boldsymbol{m}^{+}$ & - & C. Collins \\
\hline
\end{tabular}

* Addresses: M. Horwitz, UCLA Medical School, Los Angeles, CA, USA; R. Miller, University of Louisville School of Medicine, Louisville, KY, USA; J. F. Plouffe, Ohio State University, Columbus, OH, USA; A. Marra, Massachusetts Institute of Technology, Boston, MA, USA; C. Collins, University of Miami School of Medicine, Miami, FL, USA.

not contribute to the ability of $L$. pneumophila to enter or grow within eukaryotic cells.

\section{Methods}

Bacterial strains and growth media. The bacterial strains used in this study are listed in Table 1. L. pneumophila was routinely grown in Albumin Yeast Extract (AYE) broth and on ACES-buffered Charcoal Yeast Extract (ABCYE) agar plates at $37^{\circ} \mathrm{C}$ as previously described (Mintz \& Shuman, 1988). Strains of Escherichia coli were grown at $37^{\circ} \mathrm{C}$ on L-agar or in L-broth. When necessary, the following antibiotic concentrations were used: streptomycin $(\mathrm{Sm}), 50 \mu \mathrm{g} \mathrm{ml}^{-1}$; rifampicin (Rif), $20 \mu \mathrm{g} \mathrm{ml}^{-1}$; kanamycin ( $\left.\mathrm{Km}\right), 25 \mu \mathrm{g} \mathrm{ml}^{-1}$; ampicillin (Ap), $50 \mu \mathrm{g} \mathrm{ml}^{-1}$ and tetracycline (Tc), $10 \mu \mathrm{g} \mathrm{ml}^{-1}$.

Isolation and analysis of plasmid DNA. Plasmid DNA was isolated from L. pneumophila using the rapid method of Kado \& Liu (1981) or the alkaline lysis protocol of Birnboim \& Doly (1979). In some experiments, chromosomal DNA was removed from plasmid-containing lysates by centrifugation through ethidium bromide/ $\mathrm{CsCl}$ gradients (Maniatis et al. 1982). Plasmid DNA prepared by the Kado \& Liu method was not cut by restriction endonucleases so plasmid DNA isolated by the Birnboim \& Doly method was used for restriction endonuclease analysis in this investigation. Plasmid DNA and restriction enzyme digestions of plasmid DNA were analysed by horizontal agarose gel electrophoresis using $0.4 \%$ and $0.7 \%$ agarose (Bio-Rad) gels.

Cloning of pCHI DNA. CsCl-purified pCH1 DNA was digested with the restriction enzyme SalI (Promega), ligated with SalI-cleaved, alkaline-phosphatase-treated pBR322 DNA and transformed into $\mathrm{CaCl}_{2}$-treated $E$. coli DH5a. Transformants were selected on L-agar supplemented with ampicillin and putative recombinants were identified by their $\mathrm{Ap}^{\mathrm{r}} \mathrm{Tc}^{\mathrm{s}}$ phenotypes. The presence of $\mathrm{pCH} 1$ sequences in recombinant plasmids was confirmed by Southern hybridization using ${ }^{32} \mathrm{P}$-labelled $\mathrm{pCH} 1 \mathrm{DNA}$ as a probe.

Mating experiments. Donor strain $\mathrm{CH}-1$ (which harbours $\mathrm{pCH} 1$ and contains no antibiotic-resistance markers) and antibiotic-resistant plasmidless recipients were grown to early exponential phase in AYE broth at $37^{\circ} \mathrm{C}$. Equal numbers of donors and recipients were incubated together on non-selective ABCYE plates at $37^{\circ} \mathrm{C}$ for $18 \mathrm{~h}$ as described by Mintz \& Schuman (1988). After incubation, cells were removed from the plates, serially diluted in M63 salts buffer (Silhavy et al., 1984) and spread onto ABCYE agar plates that contained appropriate antibiotics (Sm, Rif or $\mathrm{Km}$ ) to counterselect the donor strain $\mathrm{CH}-\mathrm{l}$. In some matings, strains that contained two or more drug markers were used as recipients. In these experiments, $\mathrm{ABCYE}$ agar that contained two antibiotics was used to counterselect $\mathrm{CH}-1$. The plates were incubated at $37^{\circ} \mathrm{C}$. Colonies were replica-plated onto nitrocellulose filters, lysed with $\mathrm{NaOH}$, probed with ${ }^{32} \mathrm{P}$-labelled pBR322 DNA (containing a $21.0 \mathrm{~kb}$ Sall fragment from $\mathrm{pCH} 1$ ) and subjected to 
autoradiography. We routinely screened approximately 2000-3000 transconjugants for the presence of pCH1 DNA. Preliminary experiments showed that ${ }^{32} \mathrm{P}$-labelled pBR322 DNA by itself did not hybridize with $\mathrm{pCH} 1$ or L. pneumophila chromosomal DNA. Hybridizations were performed under conditions of high stringency (Silhavy et al., 1984). Colonies that hybridized with the probe were picked from master plates and purified twice by passage on selective media. Plasmid DNA was isolated from these colonies, digested with SalI and examined by agarose gel electrophoresis. All mating experiments were repeated at least two times.

For mating experiments involving DNAase treatment, equal numbers of donors and recipients were incubated for $18 \mathrm{~h}$ at $37^{\circ} \mathrm{C}$ on ABCYE agar that contained $1 \mathrm{mg}$ DNAase $\mathrm{ml}^{-1}$. Cells were then removed from the plates and spread onto antibiotic-containing ABCYE agar as described above.

Chromosome mobilization experiments using strain $\mathrm{CH}-1$ as a donor and auxotrophic mutants of strains Bloomington-2 (Gua- and Trp ${ }^{-}$) and Philadelphia-1 ( hhy $^{-}$and $\mathrm{Trp}^{-}$) as recipients were done according to Mintz \& Schuman (1988).

Colony immunoblast assay. Single colonies of donors, recipients and transconjugants were inoculated onto $0.45 \mu \mathrm{m}$ nitrocellulose filters (Fisher) placed on ABCYE agar plates and incubated for 24-48 h at $37^{\circ} \mathrm{C}$. Filters were removed from the plates and incubated in Trisbuffered saline (TBS; $50 \mathrm{~mm}$-Tris/HCl, $150 \mathrm{~mm}-\mathrm{NaCl}, \mathrm{pH} 7.5$ ) containing $5 \%(\mathrm{w} / \mathrm{v})$ nonfat dried milk (Carnation) for $2 \mathrm{~h}$ at room temperature. The filters were washed several times with TBS and incubated with monoclonal antibody (mAb) 1 E6 ( $1: 1000$ dilution) on a rotary shaker (New Brunswick) for $1 \mathrm{~h}$ at room temperature. mAb $1 \mathrm{E} 6$ (kindly provided by W. Johnson, University of Iowa, USA) is specific for serogroup 1 lipopolysaccharide. After incubation, the filters were washed several times with TBS and probed with horseradishperoxidase-conjugated goat-antimouse IgG antibodies (1:1000 dilution, Cappel) for $1 \mathrm{~h}$ at room temperature. After a series of four washes with TBS, filters were immersed in a solution of $0.05 \%$ 4-chloro-1naphthol (Sigma) and 0.015\% hydrogen peroxide.

Antibiotic and heavy metal resistance. The ability of $\mathrm{pCH} 1$ to confer resistance to antibiotics or heavy metals was tested in the following manner. Single colonies of isogenic plasmidless and $\mathrm{pCH} 1$-containing strains of $L$. pneumophila were inoculated onto ABCYE agar and ABCYE agar containing a specific antibiotic or heavy metal. The plates were incubated at $37^{\circ} \mathrm{C}$ for $5 \mathrm{~d}$. Resistance to the following heavy metals was tested using the concentrations suggested by Trevors et al. (1985): cadmium chloride (1 mM), sodium arsenate ( $38 \mathrm{~mm})$, cobalt chloride ( $3 \mathrm{mM})$, copper sulphate $(20 \mathrm{mM})$, lead nitrate $(0.3 \mathrm{mM})$, nickel chloride ( $3 \mathrm{mM})$, zinc chloride ( $1 \mathrm{mM}$ ) and silver nitrate (5 mM). Antibiotics were tested at the concentrations mentioned above.

Infection of U937 cells and Hartmannella vermiformis with $L$. pneumophila. Human-monocyte-like cells (U937) were infected with legionellae as previously described (King et al., 1991). U937 cell monolayers were grown in RPMI 1640 (Cellgro) plus 20\% (v/v) normal human serum for up to $3 \mathrm{~d}$ at $37^{\circ} \mathrm{C}$ in $5 \%(\mathrm{v} / \mathrm{v}) \mathrm{CO}_{2}$. At daily intervals, samples were removed from the infected monolayers, diluted in M63 salts buffer and plated on ABCYE agar to determine numbers of L. pneumophila.

Plate-grown legionellae were co-cultured with the amoeba $H$. vermiformis at $35^{\circ} \mathrm{C}$ for $7 \mathrm{~d}$ according to King et al. (1991). At various times, samples were removed from the co-cultures, serially diluted in buffer, and plated on ABCYE agar to determine the numbers of L. pneumophila.

Previous studies using U937 cells (King et al., 1991; Pearlman et al., 1988) and $H$. vermiformis (King et al., 1991) demonstrated that any increase in numbers of $L$. pneumophila as measured above represent intracellular growth of the bacterium.

\section{Results}

\section{Isolation and characterization of $\mathrm{pCHI}$}

The plasmid content of five serogroup 1 strains $(\mathrm{CH}-1$, OLDA, Albuquerque 1, $\mathrm{LpP}_{2}$ and SF3256) reported to carry $85 \mathrm{MDa}$ plasmids was analysed by agarose gel electrophoresis. Each strain contained a single plasmid and the electrophoretic mobility of the plasmids was identical (data not shown). Digestion of each plasmid with SalI or BamHI yielded identical fragment patterns (data not shown). These results suggested that strains $\mathrm{CH}-1$, OLDA, Albuquerque-1, $\mathrm{LpP}_{2}$ and SF3256 harboured the same plasmid, subsequently designated pCH1.

Restriction endonuclease analysis of $\mathrm{pCH} 1$ revealed that EcoRI, HindIII or HaeIII generated $\geq 13$ restriction fragments. Digestion with $B g l \mathrm{I}, P v u I I, S a l \mathrm{I}, B g l \mathrm{II}$ or NheI yielded 5-7 restriction fragments (data not shown). pCH1 was not cleaved by NotI, SfII, ApaI or RsrII. We also determined that $\mathrm{pCH} 1$ has a single BamHI site contained within the $11 \mathrm{~kb}$ SalI restriction fragment (Fig. 1). Attempts to construct a detailed restriction map of $\mathrm{pCH} 1$ were hampered by the large number of restriction fragments generated during single and double digests and our inability to clone the majority of the plasmid genome in $E$. coli (see below). Pulse-field gel electrophoresis of BamHI-digested plasmid DNA showed that the apparent molecular size of $\mathrm{pCH} 1$ is 125 $130 \mathrm{~kb}$ (data not shown). This is in agreement with the predicted molecular size of $\mathrm{pCH} 1$, which was previously determined to be $85 \mathrm{MDa}(128 \mathrm{~kb})$.

The results from antibiotic sensitivity tests indicated that $\mathrm{pCH} 1$ did not encode resistance to Rif, Sm, Ap, Km or Tc. Neither did the plasmid confer resistance to any of the heavy metals tested. Attempts to cure $\mathrm{pCH} 1$ from plasmid-bearing strains by treatment with acridine orange (Riva et al., 1973), ethidium bromide (Bouanchaud et al., 1969), growth at $41^{\circ} \mathrm{C}$ or by repeated subculture on ABCYE agar at $37^{\circ} \mathrm{C}$ were unsuccessful. This suggested that $\mathrm{pCH} 1$ was stably maintained in $L$. pneumophila in the absence of obvious selective pressure.

\section{Cloning of $\mathrm{pCHI}$ DNA}

As shown in Fig. 1, the restriction enzyme SalI cleaves pCH1 DNA into six distinct restriction fragments. We attempted to isolate and clone each of the six SalI fragments from $\mathrm{pCH} 1$. Despite repeated attempts using either pBR322 or pACYC184 as cloning vectors, we were only able to isolate the $21.0 \mathrm{~kb}$ Sall fragment from $\mathrm{pCH} 1$. This fragment was cloned into the unique SalI site of pBR322 (Fig. 1) and subsequently used as a probe in plasmid transfer experiments. 


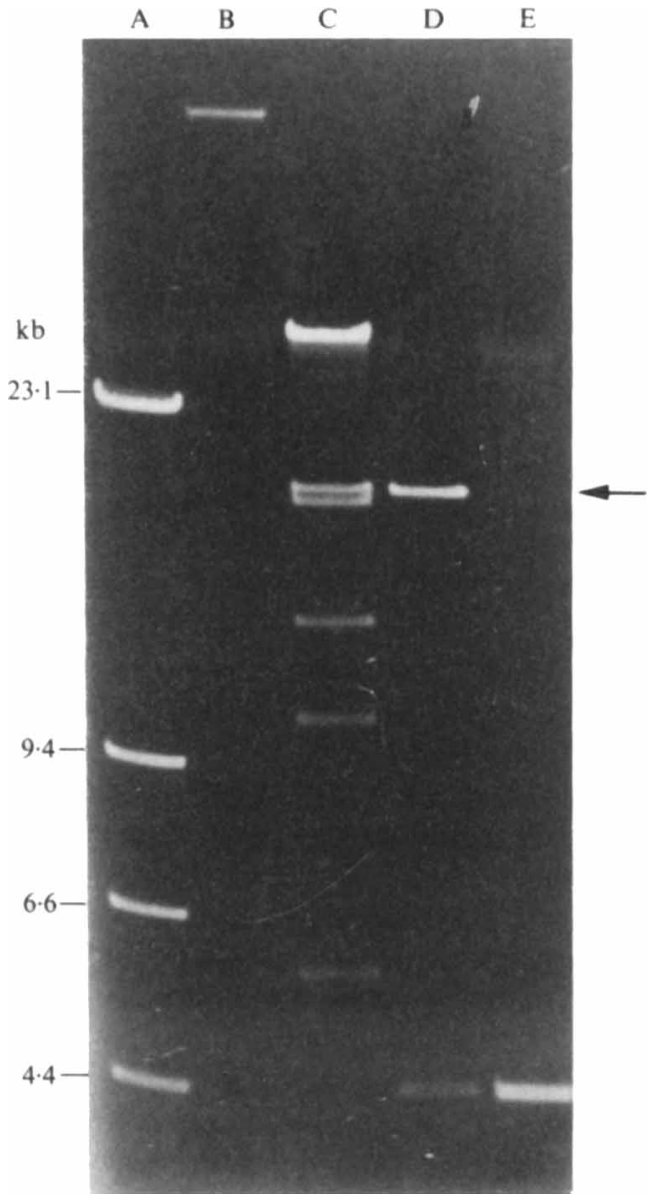

Fig. 1. Ethidium-bromide-stained $0.4 \%$ agarose gel that contains the cloned $21.0 \mathrm{~kb}$ SalI fragment of pCH1. Lanes: A, $\lambda$ HindIII molecular size standards; $\mathrm{B}$, undigested pCH1 DNA; C, pCH1 DNA digested with $S a l$ I ; D, pBR322 DNA that contains the cloned fragment digested with SalI; E, pBR322 DNA digested with SalI. Arrow indicates the position of the $21.0 \mathrm{~kb}$ fragment of $\mathrm{pCH} 1$.

\section{Conjugative transfer of $\mathrm{pCHI}$}

To determine whether $\mathrm{pCH} 1$ is conjugative, mating experiments between strain $\mathrm{CH}-1$ (which harboured pCH1) and several antibiotic-resistant plasmid-less $L$. pneumophila recipients were done. Since $\mathrm{pCH} 1$ does not encode any selectable markers, we assessed the ability of strain $\mathrm{CH}-1$ to conjugally transfer $\mathrm{pCH} 1$ by colony hybridization using the cloned $21 \mathrm{~kb}$ SalI fragment from $\mathrm{pCH} 1$ as a probe.

Initial mating experiments, in which strain AM511 was used as the recipient, revealed that several colonies on the selection plates hybridized with the $\mathrm{pCH} 1$ probe. The electrophoretic profile of SalI-digested plasmid DNA from each of these colonies was identical to that of Sall-digested pCH1 DNA (data not shown). This suggested that $\mathrm{pCH} 1$ was transferred by a mating process. However, the possibility existed that colonies that contained $\mathrm{pCH} 1$ were spontaneous antibioticresistant mutants of strain $\mathrm{CH}-1$ rather than actual transconjugants. To eliminate this possibility, we did additional mating experiments using multiple-antibioticresistant recipients in which two antibiotics were used to counterselect donor strain $\mathrm{CH}-1$. The frequency of spontaneous mutation to resistance for two antibiotics for strain $\mathrm{CH}-1$ would be approximately $10^{-12}$. However, pCH1 was detected in exconjugants at frequencies ranging from $10^{-3}-10^{-4}$ per recipient. These results supported the idea that colonies that contained $\mathrm{pCH} 1$ were transconjugants rather than antibiotic-resistant mutants of strain $\mathrm{CH}-1$. This was confirmed by colony immunoblot experiments with putative transconjugants using mAb $1 \mathrm{E} 6$, which does not bind to strain $\mathrm{CH}-1$ but is reactive with each of the other serogroup 1 strains used as recipients in this study. In all cases, colonies that hybridized with the $\mathrm{pCH} 1$ probe also bound $\mathrm{mAb} 1 \mathrm{E} 6$ (data not shown). This demonstrated that $\mathrm{pCH} 1$ was transferred from strain $\mathrm{CH}-1$ to $L$. pneumophila recipients during the mating process. The detection of $\mathrm{pCH} 1$ in transconjugants obtained from matings in the presence of DNAase $\left(1 \mathrm{mg} \mathrm{ml}^{-1}\right)$ provided conclusive evidence that $\mathrm{pCH} 1$ was selftransmissible by conjugation (data not shown).

A summary of the mating experiments done in this study is presented in Table 2. By determining the number of pCH1-containing colonies among the total number of transconjugants screened, we estimated that $\mathrm{pCH} 1$ was transferred at frequencies ranging from $10^{-3}-10^{-4}$ per recipient. Of interest, $\mathrm{pCH} 1$ could only be conjugally transferred into serogroup 1 recipients. We were unable to detect transfer of $\mathrm{pCH} 1$ into a serogroup 3 recipient (strain Bloomington-2) or E. coli $\mathrm{DH} 5 \alpha$. Additional mating experiments between strain $\mathrm{CH}-1$ and several serogroup 1 or serogroup 3 auxotrophic recipients showed that $\mathrm{pCH} 1$ could not promote the chromosomal transfer of the gua, thy or trp loci in L. pneumophila (data not shown).

\section{pCH1 does not share homology with L. pneumophila chromosomal DNA or other indigenous plasmids}

To determine if $\mathrm{pCH} 1$ shared DNA homology with other L. pneumophila plasmids or with L. pneumophila chromosomal DNA, we performed colony hybridization experiments with plasmid-less and plasmid-containing strains of $L$. pneumophila. In these experiments, $\mathrm{CsCl}$-purified pCH1 DNA labelled with ${ }^{32} \mathrm{P}$ was used as a probe. $\mathrm{pCH} 1$ DNA did not hybridize with strains of $L$. pneumophila that contained indigenous plasmids other than $\mathrm{pCH} 1$ (strains UH-2, UPH-1, Atlanta-1 and Atlanta-4; Fig. 2). This suggested that $\mathrm{pCH} 1$ does not share detectable 

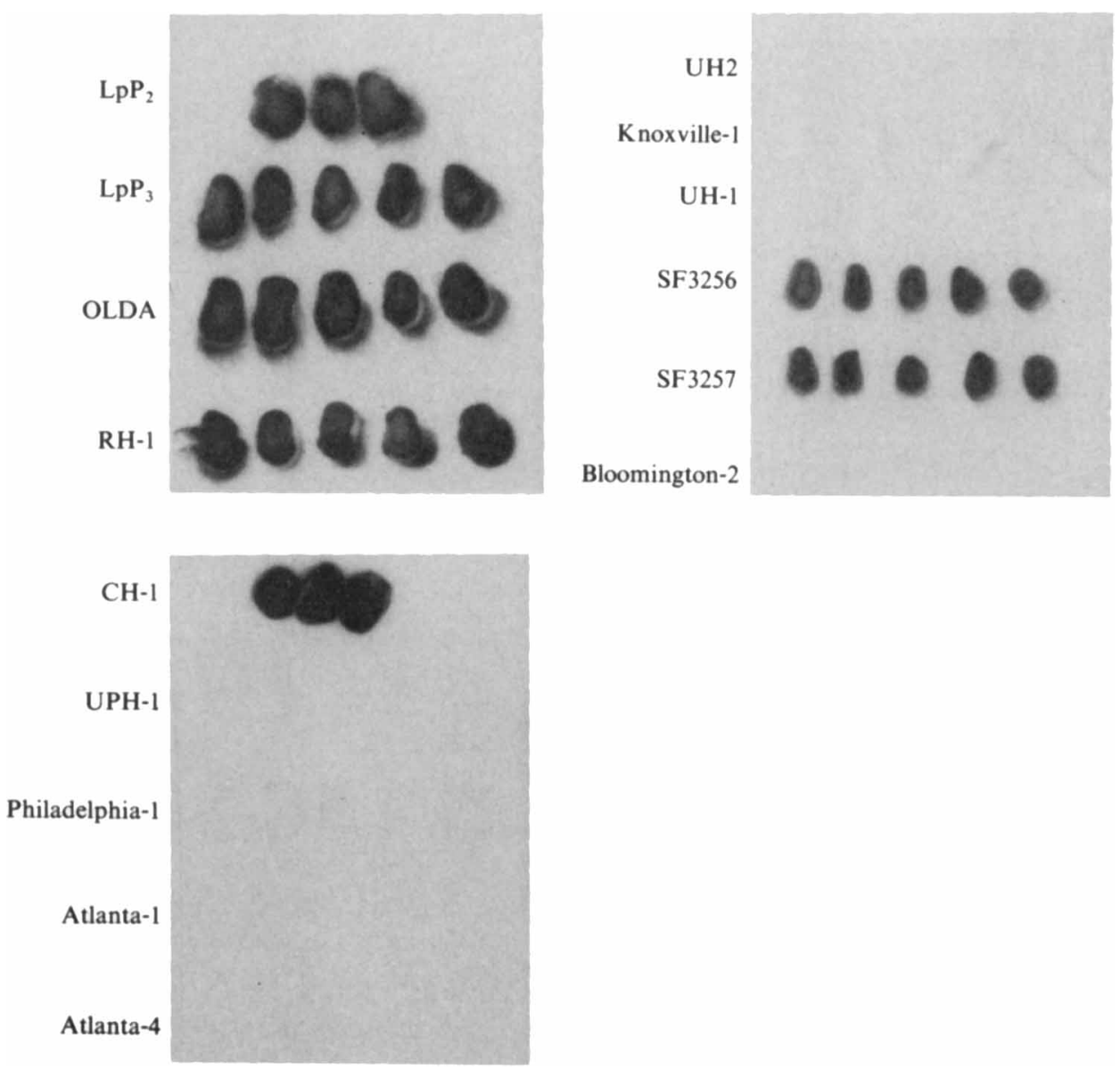

Fig. 2. Colony hybridization experiments with plasmid-less and plasmid-bearing strains of L. pneumophila. Individual colonies from plasmid-less and plasmid-bearing strains of $L$. pneumophila were patched onto nitrocellulose filters, treated with $\mathrm{NaOH}$ and probed with ${ }^{32} \mathrm{P}$-labelled $\mathrm{CsCl}$-purified pCH1 DNA. Colonies that hybridized with the probe were visualized by autoradiography. Only those strains that harboured an $85 \mathrm{MDa}$ plasmid hybridized with the $\mathrm{pCH} 1$ probe.

Table 2. Summary of mating experiments

Abbreviations, see Table 1.

\begin{tabular}{|c|c|c|c|c|}
\hline \multirow[b]{2}{*}{ Donor } & \multicolumn{2}{|r|}{ Recipient } & \multirow[b]{2}{*}{ Selection } & \multirow{2}{*}{$\begin{array}{l}\text { Plasmid transfer } \\
\text { detected }\end{array}$} \\
\hline & Strain & Phenotype & & \\
\hline $\mathrm{CH}-1$ & AM511 & Philadelphia-1 serogroup $1 \mathrm{Sm}^{r} r^{-} m^{+}$ & $\mathrm{Sm}$ & Yes \\
\hline $\mathrm{CH}-1$ & $\mathrm{CS} 267$ & Philadelphia-1 serogroup $1 \mathrm{Sm}^{\mathrm{r}} \mathrm{Rif}^{\mathrm{r}} r^{-} m^{+}$ & Sm Rif & Yes \\
\hline $\mathrm{CH}-\mathrm{I}$ & $\mathrm{CZ3001}$ & Philadelphia-1 serogroup $1:: \mathrm{Tn} 5 m o b \mathrm{Km}^{\mathrm{r}} \mathrm{Sm}^{\mathrm{r}} r^{-} m^{+}$ & $\mathrm{Km} \mathrm{Sm}$ & Yes \\
\hline $\mathrm{CH}-1$ & $\mathrm{CS} 320$ & Knoxville-1 serogroup $1 \mathrm{Sm}^{\mathrm{r}} \mathrm{Rif}^{\mathrm{r}}$ & Sm Rif & Yes \\
\hline $\mathrm{CH}-1$ & $\mathrm{CS} 2$ & Bloomington-2 serogroup $3 \mathrm{Sm}^{\mathrm{r}} \mathrm{r}^{-} \mathrm{m}^{-}$ & $\mathrm{Sm}$ & No \\
\hline $\mathrm{CH}-1$ & CS302 & Bloomington-2 serogroup $3 \mathrm{Rif}^{\mathrm{T}} \mathrm{Trp}^{-} r^{-} m^{-}$ & Rif & No \\
\hline $\mathrm{CH}-1$ & DH5 $\alpha$ & Escherichia coli $\mathrm{Nal}^{\mathrm{r}} r^{-} m^{+}$ & $\mathrm{Nal}$ & No \\
\hline
\end{tabular}

DNA homology with other Legionella plasmids. In contrast, all of the L. pneumophila strains that contained an $85 \mathrm{MDa}$ plasmid hybridized with the probe $\left(\mathrm{LpP}_{2}\right.$, LpP $_{3}$, OLDA, RH-1, SF3256 and SF3257; Fig. 2).
The plasmid-less serogroup 1 strains Philadelphia-1, Knoxville-1 and UH-1 did not hybridize with $\mathrm{pCH} 1$ DNA (Fig. 2). Also, the plasmid-less serogroup 3 strain, Bloomington-2, did not hybridize with $\mathrm{pCH} 1$. 


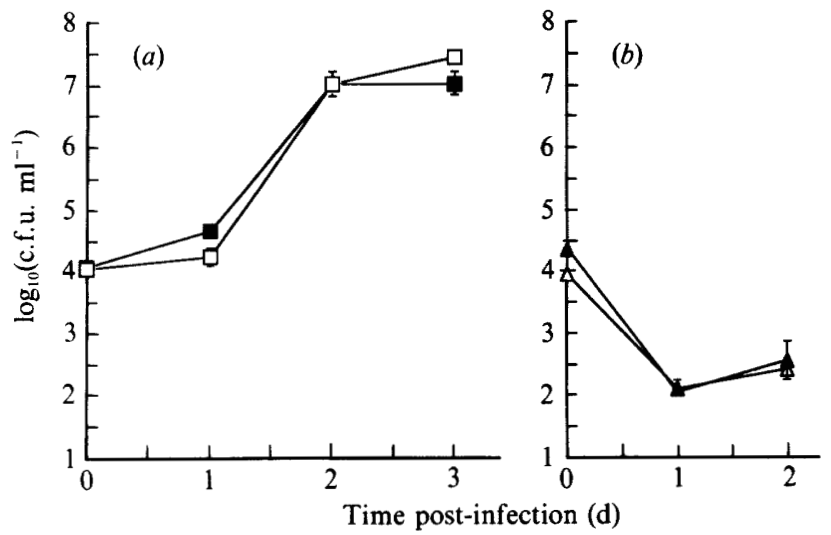

Fig. 3. Infection of U937 cell monolayers with isogenic plasmid-less and plasmid-bearing strains of L. pneumophila. U937 cell monolayers were infected with $L$. pneumophila according to the methods of King et al. (1991). (a) $\square$, AM511; $\square$, AM511(pCH1). (b) A, CS323; $\triangle, \mathrm{CS} 323(\mathrm{pCH} 1)$. Each point represents the mean \pm SE for three separate U937 cell cultures.

Additional experiments demonstrated that $\mathrm{pCH} 1 \mathrm{DNA}$ also did not hybridize with the plasmid-less serogroup 1 strains Pontiac-1, NY 26 and Ver 5, or the plasmid-less serogroup 4 strain Rockport (data now shown). This suggests that these strains do not contain chromosomal sequences homologous with pCH1 DNA.

\section{$p C H 1$ does not affect the intracellular growth of}

\section{L. pneumophila}

Using the mating procedure outlined above, we introduced pCH1 into strains AM511 and CS323 to construct isogenic pairs of plasmid-less and plasmidcontaining strains. Strain AM511 is virulent and capable of intracellular growth (Marra \& Shuman, 1989). In contrast, strain CS323 is avirulent and incapable of intracellular multiplication (C. S. Mintz, unpublished). Both isogenic sets were used to infect monocyte-like U937 cells or the amoeba Hartmannella vermiformis. pCH1 did not affect the ability of strain AM511 to multiply in U937 cells (Fig. $3 a$ ) or in H. vermiformis (data not shown). Moreover, the plasmid did not restore the ability of the avirulent strain CS323 to replicate in either U937 cells (Fig. $3 b$ ) or in $H$. vermiformis (data not shown).

\section{Discussion}

In this study, we have shown that $\mathrm{pCH} 1$, an indigenous $L$. pneumophila plasmid, is self-transmissible by conjugation among serogroup 1 strains of L. pneumophila. Prior to the present study, we (Mintz \& Shuman, 1988) as well as others (Dreyfus \& Iglewski, 1985; Chen et al., 1986) demonstrated that broad host range plasmids of the IncP and IncQ incompatibility groups could easily be transferred via conjugation between different $L$. pneumophila isolates. Recently, Tully (1991) demonstrated that a $36 \mathrm{MDa}$ plasmid from $L$. pneumophila strain Dodge (serogroup 1) could be transferred by conjugation to other serogroup 1 strains. Our results, along with those of Tully (1991), suggest that conjugation mediated by indigenous plasmids may be a mechanism of genetic exchange for $L$. pneumophila. To date, neither transformation nor transduction has been reported for $L$. pneumophila.

Despite repeated attempts, we were unable to detect conjugative transfer of $\mathrm{pCH} 1$ into a serogroup 3 strain (Bloomington-2) of L. pneumophila. This was somewhat surprising since strain Bloomington-2 lacks the LpnII restriction-modification system of $L$. pneumophila (Marra \& Shuman, 1989), and is an excellent recipient in homologous and heterospecific matings involving IncP and IncQ plasmids (Chen et al., 1984; Mintz \& Shuman, 1988). It is not clear why we were unable to detect transfer of $\mathrm{pCH} 1$ in strain Bloomington-2. It is possible that pCH1 cannot be stably maintained in this strain. Experiments are underway to determine if $\mathrm{pCH} 1$ can be transferred by conjugation into strains from other serogroups of $L$. pneumophila. pCH1 could not be transferred from strain $\mathrm{CH}-1$ into $E$. coli strain $\mathrm{DH} 5 \alpha$. Since the $36 \mathrm{MDa}$ plasmid described by Tully (1991) could also not be transferred from serogroup 1 strains of L. pneumophila into E. coli or Pseudomonas aeruginosa, it would seem that conjugative $L$. pneumophila serogroup 1 plasmids have a relatively narrow host range.

Colony hybridization experiments revealed that $\mathrm{pCH} 1$ did not share detectable DNA homology with the 24, 33, 45 or $62 \mathrm{MDa}$ plasmids harboured by certain serogroup 1 strains of $L$. pneumophila, and that pCH1 was not related to these other L. pneumophila plasmids (Fig. 2). Therefore, it is likely that $\mathrm{pCH} 1$ belongs to a different incompatibility group than these other $L$. pneumophila plasmids. In support of this idea, the $45 \mathrm{MDa}$ plasmid has been found in two serogroup 1 strains that also harbour $\mathrm{pCH} 1$, viz. RH-1 (Maher et al. 1983) and $\mathrm{LpP}_{3}$ (C. S. Mintz, unpublished). Attempts to assign $\mathrm{pCH} 1$ to a known incompatibility group have been hampered by the lack of a selective marker on $\mathrm{pCH} 1$ and the difficulty associated with introducing plasmid DNA into $L$. pneumophila. Recently, we determined that electroporation is an efficent way of delivering plasmid DNA into $L$. pneumophila (C. S. Mintz \& C.-H. Zou, unpublished). This should permit future experiments designed to identify the incompatibility group of $\mathrm{pCH}$.

It is well-established that the transfer of chromosomal 
genes during conjugation results from integration of a conjugative plasmid, such as $\mathrm{F}$, into the donor chromosome (Deich \& Green, 1987; Silhavy et al., 1984). Integration of plasmid DNA into the host chromosome usually occurs by recombination between homologous DNA sequences contained on the plasmid and the chromosome (Bartowsky et al., 1987; Brenton et al., 1985). As previously noted, several plasmid-less $L$. pneumophila strains failed to hybridize with the $\mathrm{pCH} 1$ probe in colony hybridization experiments. These results indicate that there is no detectable DNA homology between the $L$. pneumophila chromosome and $\mathrm{pCH} 1$. This finding could explain the inability of $\mathrm{pCH} 1$ to mobilize the L. pneumophila chromosome. In the absence of DNA sequence homology, $\mathrm{pCH} 1$ would be unable to integrate into the $L$. pneumophila chromosome. Consequently, the unintegrated plasmid would be incapable of promoting the transfer of chromosomal markers. Of interest, Bartowsky et al. (1987) suggested that the lack of chromosome mobilizing activity exhibited by a conjugative plasmid from Vibrio cholerae was due to the lack of significant homology between the $V$. cholerae chromosome and the plasmid. Thus, although $\mathrm{pCH} 1$ is selftransmissible by conjugation, it is not capable of promoting detectable chromosomal gene transfer in $L$. pneumophila.

Virulence plasmids are essential for the pathogenicity of a variety of intracellular pathogens including Salmonella spp. (Gulig, 1990), Shigella spp. (Maurelli \& Sansonetti, 1988) and Yersinia spp. (Portnoy et al., 1981, 1984). In the light of these observations, we evaluated the contribution of $\mathrm{pCH} 1$ to the ability of $L$. pneumophila to multiply intracellularly in eukaryotic cells. The introduction of $\mathrm{pCH} 1$ into the plasmid-less, virulent strain AM511 did not augment or alter the ability of this strain to grow within U937 cells or $H$. vermiformis. Moreover, the presence of pCH1 in the avirulent strain CS323 did not restore its ability to multiply in U937 cells or $H$. vermiformis. These results indicate that $\mathrm{pCH} 1$ does not encode factors that contribute to the intracellular growth of $L$. pneumophila within eukaryotic host cells. Our results are consistent with the findings of Bollin et al. (1985) who compared the ability of a plasmid-less and plasmid-containing serogroup 1 strain to infect guinea pigs following intreperitoneal injection. The plasmidcontaining strain harboured $\mathrm{pCH} 1$ and a $45 \mathrm{MDa}$ plasmid. Their results showed that there was no statistically significant difference in the $\mathrm{ID}_{50}$ of the plasmid-less or plasmid-bearing strain. Interestingly, the $\mathbf{L D}_{50}$ of the plasmid-less strain was significantly lower (approximately 10-fold) than that of the plasmidcontaining strain. However, it is important to note that the plasmid-less and plasmid-containing strains used in this study were not isogenic. Therefore, it is difficult to attribute the reduced virulence exhibited by the plasmidcontaining strain to the presence of $\mathrm{pCH} 1$ or the $45 \mathrm{MDa}$ plasmid. Nonetheless, our results suggest that $\mathrm{pCH} 1$ is not required for expression of virulence by $L$. pneumophila.

Although pCH1 cannot mobilize the L. pneumophila chromosome, the self-transmissible nature of the plasmid suggests that it may contribute to the exchange of genetic information among serogroup 1 isolates. For example, the acquisition by $\mathrm{pCH} 1$ of transposons which code for antibiotic resistance could pose serious problems in the treatment of Legionnaires' disease. Moreover, the presence of transposons on $\mathrm{pCH} 1$ could facilitate integration of the plasmid into the $L$. pneumophila chromosome by transposon-mediated recombination (Ichige et al., 1989, Pischl \& Farrand, 1983). This, in turn, could promote $\mathrm{Hfr}$-like chromosomal gene transfer in L. pneumophila. In support of this notion, we have previously demonstrated that conjugative plasmids that contain transposons can be used to mobilize the $L$. pneumophila chromosome (Mintz \& Shuman, 1988).

At the present time, it is not clear what functions are encoded by $\mathrm{pCH} 1$. It does not encode resistance to any of the antibiotics or heavy metals tested nor does it contribute to the intracellular growth of L. pneumophila. The absence of pCH1 in many environmental and clinical serogroup 1 isolates suggests that any function(s) encoded by the plasmid are not essential for the survival of $L$. pneumophila in aquatic environments or in the infected host.

We thank M. Horwitz, R. Miller, J. Plouffe and C. Collins for supplying us with strains used in this study. This work was supported by a research grant awarded to C. Mintz from the American Lung Association of Florida.

\section{References}

Bartowsky, E. J., Morelli, G., Kamke, M. \& Manning, P. (1987), Characterization and restriction analysis of the $P$ sex factor and the cryptic plasmid of Vibrio cholerae strain V58. Plasmid 18, 1-7.

Ben-Gurion, R. \& Shafferman, A. (1981). Essential virulence determinants of different Yersinia species are carried on a common plasmid. Plasmid 5, 183-187.

BiRnBoim, H. C. \& Doly, J. (1979). A rapid alkaline extraction procedure for screening recombinant plasmid DNA. Nucleic Acids Research 7, 1513-1523.

Bollin, C. E., Plouffe, J. F., Para, M. F. \& Prior, R. B. (1985). Difference in virulence of environmental isolates of Legionella pneumophila. Journal of Clinical Microbiology 21, 674-677.

Bouanchaud, D. H., Scavizzi, M. R. \& Chabbert, Y. A. (1969). Elimination by ethidium bromide of antibiotic resistance in enterobacteria and staphylococci. Journal of General Microbiology 54 , 417-425.

Brenton, A. M., JaOuA, S. \& Guespin-Michel, J. (1985). Transfer of plasmid RP4 to Myxococcus xanthus and evidence for its integration into the chromosome. Journal of Bacteriology 161, 523-528. 
Chen, G. C. C., Lema, M. \& Brown, A. (1984). Plasmid transfer into members of the Legionellaceae. Journal of Infectious Diseases 150, 513-516.

Chen, G. C. C., Brown, A. \& Lema, M. W. (1986). Restriction endonuclease activities in the legionellae. Canadian Journal of Microbiology 32, 591-593.

DeICH, R. A. \& GreEn, B. A. (1987). Mobilization of Haemophilus influenzae chromosomal markers by an Escherichia coli $\mathrm{F}^{\prime}$ factor. Journal of Bacteriology 169, 1905-1910.

DREYFUS, L. A. (1987). Virulence associated ingestion of Legionella pneumophila by HeLa cells. Microbial Pathogenesis 3, 45-52.

Dreyfus, L. A. \& IGlewsKI, B. H. (1985). Conjugation-mediated genetic exchange in Legionella pneumophila. Journal of Bacteriology 161, 80-84.

Fields, B. S., Barbaree, J. M., Shotts, E. B., Feeley, J. C., Morrill, W., Sanden, G. S. \& Dykstra, M. J. (1986). Comparison of the guinea pig and protozoan models for determining virulence of Legionella species. Infection and Immunity 53, 553-559.

GULIG, P. A. (1990). Virulence plasmids of Salmonella typhimurium and other salmonellae. Microbial Pathogenesis 8, 3-11.

Holden, E. P., Winkler, H. H., WoOd, D. O. \& Leinbach, E. D. (1984). Intracellular growth of Legionella pneumophila within Acanthamoeba castellanii Neff. Infection and Immunity 45, 18-24.

Horwitz, M. A. \& Silverstein, S. C. (1980). Legionnaires disease bacterium (Legionella pneumophila) multiplies intracellularly in human monocytes. Journal of Clinical Investigation 66, 441-450.

Ichige, A., Matsutani, S., Oishi, K. \& Mizushima, S. (1989). Establishment of gene transfer systems for and construction of the genetic map of a marine Vibrio strain. Journal of Bacteriology 171, 1825-1834.

Johnson, S. R. \& Schalla, W. O. (1982). Plasmids of serogroup 1 strains of Legionella pneumophila. Current Microbiology 7, 143146.

KADO, C. I. \& LIU, S. T. (1981). Rapid procedure for detection and isolation of large and small plasmids. Journal of Bacteriology 145, 1365-1373.

King, C. H., Fields, B. S., Shotts, E. B. \& White, E. H. (1991). Effects of cytochalasin D and methylamine on intracellular growth of Legionella pneumophila in amoebae and human monocyte-like cells. Infection and Immunity 59, 758-763.

KnUdson, G. B. \& Mikesell, P. (1980). A plasmid in Legionella pneumophila. Infection and Immunity 29, 1092-1095.

Maher, W. E., Plouffe, J. F. \& Para, M. F. (1983). Plasmid profiles of clinical and environmental isolates of Legionella pneumophila serogroup 1. Journal of Clinical Microbiology 18, 1422-1423.
Maniatis, T., Fritsch, E. F. \& Sambrook, J. (1982). Molecular Cloning: a Laboratory Handbook. Cold Spring Harbor, NY: Cold Spring Harbor Laboratory.

MARRA, A. \& ShUman, H. A. (1989). Isolation of a Legionella pneumophila restriction mutant with increased ability to act as a recipient in heterospecific matings. Journal of Bacteriology 171, 2238-2240.

Maurelli, A. T. \& Sansonetti, P. J. (1988). Genetic determinants of Shigella pathogenicity. Annual Review of Microbiology 42, 127-150.

Mikesell, P., Ezzell, J. W. \& KnUdson, G. B. (1981). Isolation of plasmids in Legionella pneumophila and Legionella-like organisms. Infection and Immunity 31, 1270-1272.

MinTZ, C. S. \& Schuman, H. A. (1988). Genetics of Legionella pneumophila. Microbiological Sciences 5, 292-295.

Newsome, A. L., Baker, R. L., Miller, R. D. \& ARnold, R. R. (1985). Interactions between Naegleria fowleri and Legionella pneumophila. Infection and Immunity 50, 449-452.

Pearlman, D., Jiwa, A. H., Engelberg, N. C. \& Eisenstein, B. I. (1988). Growth of Legionella pneumophila in a human macrophagelike (U937) line. Microbial Pathogenesis 5, 87-95.

PisChL, D. L. \& FARRAND, S. K. (1983). Transposon-facilitated chromosome mobilization in Agrobacterium tumefaciens. Journal of Bacteriology 153, 1451-1460.

Portnoy, D. L., Mosely, S. L. \& FalKow, S. (1981). Characterization of plasmids and plasmid associated determinants of Yersinia enterocolitica pathogenesis. Infection and Immunity 21, 75-78.

Portnoy, D. A., Wolf-Watz, H., Bolin, I., Breeder, A. B. \& FALKOW, S. (1984). Characterization of common virulence plasmids in Yersinia species and their role in the expression of outer membrane proteins. Infection and Immunity 43, 108-114.

Riva, S., Fietta, A., Berti, M., Silvestri, G. \& Romero, E. (1973). Relationships between curing of the $\mathrm{F}$ episome by rifampin and by acridine orange in Escherichia coli. Antimicrobial Agents and Chemotherapy 3, 456-462.

RowbothaM, T. J. (1986). Current views on the relationships between amoebae, legionellae and man. Israel Journal of Medical Sciences 22, 678-689.

Silhavy, T. J., Berman, M. L. \& ENQuist, L. W. (1984). Experiments with Gene Fusions. Cold Spring Harbor, NY: Cold Spring Harbor Laboratory.

Trevors, J. T., Oddie, K. M. \& Belliveau, B. H. (1985). Metal resistance in bacteria. FEMS Microbiology Reviews 32, 39-54.

Tully, M. (1991). A plasmid from a virulent strain of Legionella pneumophila is conjugative and confers resistance to ultraviolet light. FEMS Microbiology Letters 90, 43-48. 